Estuarine, Coastal and Shelf Science

December 2016, Volume 182, Part B, Pages 229-234

http://dx.doi.org/10.1016/i.ecss.2016.07.010

http://archimer.ifremer.fr/doc/00346/45698/

(c) 2016 Elsevier Ltd. All rights reserved.

\title{
Integrated management of pearl culture in French Polynesia in the context of global change: Synopsis of existing results
}

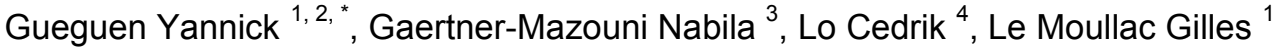

${ }^{1}$ Ifremer, UMR 241 EIO, LabexCorail, BP 49, 98719 Taravao, French Polynesia

2 Ifremer, UMR 5244 IHPE, UPVD, CNRS, Université de Montpellier, CC 80, F-34095 Montpellier, France

${ }^{3}$ Université de Polynésie Française, UMR 241 EIO, Labex Corail, BP 6570, 98702 Faa'a, Tahiti, French Polynesia

${ }^{4}$ Direction des Ressources Marines et Minières, BP 20, 98713 Papeete, Tahiti, French Polynesia

* Corresponding author : Yannick Gueguen, email address : yqueguen@ifremer.fr

\begin{abstract}
:
The paper presents a state of the art on knowledge of the black pearl oyster aquaculture at the scale of French Polynesia. It also introduces the main results obtained throughout the multi-partners POLYPERL project. The goal of this project was to develop an integrated and participative action-research of the pearl oyster culture system, focusing on the environmental, technological, economical and societal dimensions impacting the industry. The research proposed ranges from the understanding of biological phenomena of the production system to socio-economic aspects and governance of the industry, taking into account the management of anthropogenic, climate and health risks. We introduce here the different papers from the POLYPERL project that are compiled in this volume of ECSS dealing with recent scientific work that can contribute to sustainability of the pearl industry in French Polynesia.
\end{abstract}

\section{Graphical abstract}

We introduce the different papers from the POLYPERL project that are compiled in this volume of ECSS dealing with recent scientific work on pearl oyster culture. The main research programms of these last years on pearl oyster culture are presented with a focus on the influence of global change. The importance of the socio-economic aspects of this industry is also highlighted. 


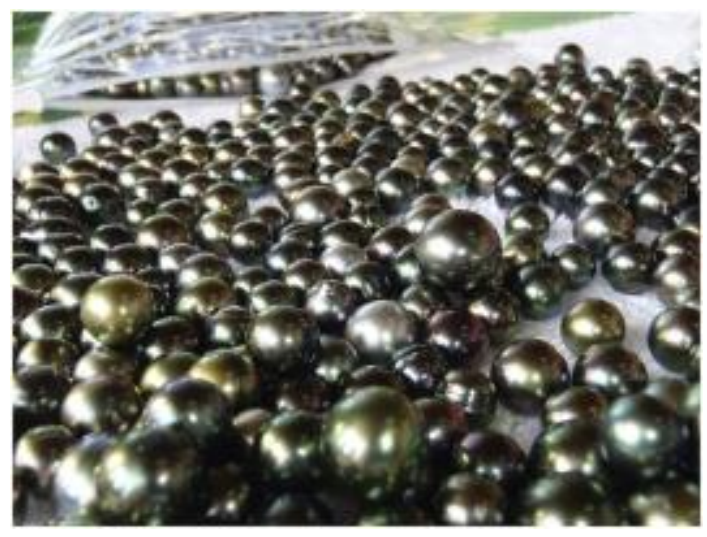

\section{Highlights}

- Pearl culture has become one of the most important industries in French Polynesia. This industry is currently undergoing an unprecedented crisis. POLYPERL is an integrated project on the pearl oyster culture system.

Keywords : Pearl culture ; Global change ; French Polynesia ; Pinctada margaritifera 


\section{1- Introduction}

Close to thirty million people worldwide depend on coral reefs. Most live from fishing, tourism or aquaculture activity. If coral reefs are not protected in time, these populations and eventually small island countries will be condemned to disappear. So, worldwide, the conservation of these ecosystem services is considered as a management priority (Millenium Assessment, 2005). This situation is particularly striking with pearl farming industry in French Polynesia.

Indeed, in 30 years, the aquaculture of black pearl culture has become one of the most important industries (second rank for exportation values) in French Polynesia (Talvard, 2015; Le Pennec et al., 2010; Andréfouet et al., 2012; Gueguen and Mazouni, 2014). However, this industry, based on the exploitation of the pearl oyster Pinctada margaritifera, is currently undergoing an unprecedented crisis. As a result of the economic decline that the industry has experienced since 2001, the pearl culture industry is in a very difficult situation. The price of the pearl has collapsed (price per pearl was divided by a factor of 8) and is still decreasing. Consequently, a large number of farms have gone bankrupt or already closed, leading to substantial job losses for the country and resulting in a resumption of migration to Tahiti. While this serious crisis is partially due to internal causes (increase of the pearl production, disorganization of the sector, significant decrease in the average quality of the pearls exported), external factors have also a great influence (evolution of the market, economic crisis, etc...). In an attempt to reverse this trend, local authorities have established regulatory tools, promoted communication events, etc., whose effectiveness in the medium term have not yet been studied, due to the lack of robust indicators.

It is in response to this situation that the project POLYPERL was designed. By making a comprehensive analysis of the different components of the industry (technical, biological, economic, health and governance), we aimed to co-construct proposals for the management strategy of the sector. For that, POLYPERL project was splitted into complementary working packages, to embrace the different components of the pearl farming industry while maintaining between them a permanent interaction (Figure 1). Project work consisted of assessing the means and levels at which technological and organizational progress can be made, taking into account maintenance of marine ecosystem capacity to provide these services. In addition, this work took into account the political, social and cultural context in which this research was conducted. Indeed, with this approach, different disciplines in the scientific community were mobilized in close association with all the industry stakeholders: producers, managers and traders. 
In this context, we show in this paper an overwiew of the pearl culture industry in French Polynesia. The main research programms of these last years on pearl oyster culture are presented with a focus on the influence of global change. The importance of the socioeconomic aspects of this industry is also highlighted. In the conclusion part, we introduce the different papers form the POLYPERL project compiles in this special issue of ECCS.

\section{2- French Polynesia and pearl culture}

French Polynesia is made up of five socio-cultural archipelagos (Société, Tuamotu, Gambier, Marquises and Australes) and comprises 118 islands and atolls. Its total area is 5.03 million $\mathrm{km}^{2}$ but the land area only accounts for $3500 \mathrm{~km}^{2}$. Located in the South Pacific, French Polynesia is an isolated region with a population of 285000 inhabitants. Pearl culture (Figure 2) indeed has a key position in Polynesia on economic, environmental and social levels. This activity, spread over 25 Polynesian islands, contributes not only to slowing down the human migration from the other islands to Tahiti, but also helps planning and economic development of these areas. Pearl culture, which is directly dependent on the health of the lagoon ecosystem, is in fact the second source of revenue after tourism and is the first export industry (Talvard C, 2015).

Pearl culture began to develop in French Polynesia in the early 1970s. The main advantage of this region, compared with other countries where the species $P$. margaritifera is present, is the spontaneous and virtually unlimited natural supply of spat (juveniles) in atoll lagoons. Rapid progress in terms of rearing and informed commercial policy succeeded in making the "Tahitian Black Pearl" a recognised luxury product that exported well to a responsive international market. High mortality of pearl oysters, which started in the mid 1980s, contributed to a scarcity of the product and thus to a significant increase in the gem price per gram. In 1986, the gem price per gram peaked at $80 €$ (Figure 3). The epidemic was quickly contained by the implementation of appropriate regulations, and by rapid advances in farming and spat collecting techniques. These advances, in turn, led to the overproduction of pearls, often at the expense of quality. Moreover, the very rapid increase in the number of rearing concessions further boosted this overproduction. In 2000, production exceeded 11 tons with a price per gram of only $15 €$. This greatly increased production and has contributed to increase in the volumes of gems exported at the expense of quality. A socio-economic analysis notes that this downward trend now appears to be stabilizing, but also reports that the situation remains fragile and at risk from another fall. 
Yet, over the last 3 decades, this activity has become essential to the economy of French Polynesia. Pearls are the top export resource, with a value of 73.7 million euros in 2014 (Figure 3). The activity, with 561 rearing concessions (in 2014), is distributed across 25 Polynesian islands, mainly in the Tuamotu Archipelago (70\%) (Talvard C, 2015. This scattering contributes significantly not only to reversing the flow of migrants from the other islands to Tahiti, but also to land-use planning, and the structural development of these pearlfarming islands. The latest statistical estimated in 2012 censused 1300 people as living from this activity. French Polynesia has more than $90 \%$ of the market, making it the world's largest producer of coloured pearls.

\section{3- Previous research on pearl oyster culture in French Polynesia}

Because the importance of Polynesian pearl farming for the economy is understood, French Polynesia encourages and participates in the running of research and development programs. From the early 90s, French Polynesia counted on research to develop and sustain the country's pearl industry. The General Research Program on Pearl Oysters (PGRN)was therefore, established in 1990. This programme gave recommendations that led to organise research. Although many studies have been made by Japanese and Australian teams on the biology of pearl oysters, their relations with the environment or processes of biomineralization, these works concern other species than that grown in Polynesia (Southgate and Lucas 2008). Very little work has been done on P. margaritifera, which is mainly reared for pearl production in French Polynesia. The need to develop an approach and working method for research and collaboration was quickly felt and research programmes were organised along the three principal orientations such as the sustainability of the pearl industry, the improvement of farm profitability and the prevention of health and environmental risks.

Under these topics, a number of actions have been undertaken. In 2003, the REPANUI network, a disease monitoring network for the pearl oyster P. margaritifera (Joly et al. 2007) has been established. This network responded to a need for animal health surveillance that arose due to the rapid growth of the pearl industry and, episodes of mass mortality that occurred in 1985 (P. margaritifera, French Polynesia) and 1997 (P. fucata, Japan). The objectives of this network are the early detection of exotic pathogens and the prevention of their spread. However, changes in rearing practices, developments in pathogen detection methods, and an increase in stock transferts are all factors that require an improved network to be established to adapt to such changes. This analysis of the situation and adaptation of the 
pearl oyster monitoring network in French Polynesia was conducted as part of the POLYPERL project, which provides an advantageous framework for exchanges with all stakeholders. The current status of shellfish farming with regard to mortalities in metropolitan France makes such preventative work all the more necessary.

The first multi-partner research project involved the establishment of a research group to improve the quality of cultured pearls from French Polynesia (ADEQUA programme, 20082012). This group was composed of a dozen laboratories, in Polynesia and metropolitan France, aiming to contribute to improve the quality of cultured pearls. Even if grafting operations have been performed in Polynesia since the 1960s, the grafting technique is however far from being standardised. The choice of donor oysters, quality of the tissue used for the graft and the physiology of the receiving oysters are decisive factors for success, but these are not sufficiently tested or technically controlled. From graft surgery to harvest, pearl culture is still done in many different ways according to the methods of each particular grafter or of pearl farmer. Such differences lead to highly variable levels of post-operative mortality, nucleus retention and pearl quality. The research conducted during this program concerns the influence of external factors on the development of pearl oysters (Linard et al, 2011, Joubert et al, 2014), the composition of the nucleus, the grafting process (Cochennec-Laureau et al, 2010) and the description of biomineralisation mechanisms (Joubert et al., 2010; Montagnani et al, 2011, Marie et al. 2012), the structure of the pearl and the selection of "donor" pearl oysters to provide tissue to be grafted (Tayale et al., 2012).

Another program involved research initiated in 2008 was supported by the IX European Development Fund as part of the program on "Professionalization and sustainability of pearl culture." The work consisted of analysing the interactions between pearl oysters and their hydro-climatic environment. It therefore required the necessary disciplines to study climate and currents in relation to ecology and ecophysiology in the context of studies on food sources and their influence on growth, reproduction and the fate of oyster larvae (Andrefouet et al., 2012, Fournier et al, 2012 a, b, Thomas et al, 2012). This project, completed in November 2010, has led to an improved characterization of the ecosystem and tools and methods can now be envisaged that will optimize spat collecting strategies, with the development of models of growth and larval transport. These results were used throughout the POLYPERL project to move towards the creation of a forecasting centre for spat collection in French Polynesia (Thomas et al., 2014).

A research project on the 'Genetic resources of Polynesian pearl culture' (REGENPERL, 2010-2014) concerns the genetic aspects of pearl oysters. The objectives of this program were 
to evaluate the impact of pearl culture on the genetics of wild pearl oyster populations and to evaluate the genetic drift linked to this activity (Chavez et al., 2011; Lemer et al, 2012). More recently, improvement of cultured pearl quality by a genetic selection program has been undertaken by selecting interesting wild donors to be used as broodstock (Ky et al., 2014). The use of a multi-trait selection program, taking into account quantitative genetic control and an improved understanding of genetic correlations necessary to avoid inadvertent selection against nontarget traits, is an effective strategy to improve cultured pearl quality and value. Extrinsic factors are studied in a dedicated experimental design to estimate the contribution of environmental variation (water conditions, temperature, trophic level, sanitary status, etc.) and human impact components (cultural practice, grafter effect, etc.) on cultured pearl quality.

\section{4- Influence of global change on the sustainability of the resource}

The life cycle of marine tropical molluscs depends on the variations in water temperature and food availability. P. margaritifera is a filtering suspension feeder that obtains food by capturing particles suspended in the water column. After a planktonic phase of about three weeks (Doroudi, et al. 2003), the larvae metamorphose into post-larvae and spat, which are able to bind to different substrates by forming byssus. In nature, substrates are scarce and there are many predators, so juvenile mortality is very high. The species compensates for this by an extraordinary high fertility, and it is this feature that is exploited by the pearl farmers during spat collection.Indeed, pearl culture in French Polynesia relies entirely on the supply of wild juveniles collected on artificial substrates. Understanding the biotic and abiotic factors that affect the success of larval development and ultimately settlement is of major concern for the industry. The trophic richness of atoll lagoons is closely linked to the level of exchange with the ocean as well as to reef geomorphology and, thus, water residence time (Pagès and Andrefouet, 2001, Dumas et al. 2012). Lagoon waters are generally described as stable and homogeneous (Delesalle et al., 2001), but several studies show strong spatio-temporal fluctuations at day, diel and vertical scales of temperature, salinity, chlorophyll or bacterial community counts (Charpy and Blanchot, 1998). Such environmental heterogeneity, liable to significantly affect the development and survival capacities of bentho-pelagic organisms, has been described in Ahe lagoon (Thomas et al., 2010; 2012 ; 2014 and Dumas et al., 2012).

The possible consequences of acidification of water bodies on pearl farming would be twofold: (i) disruption of metabolism and slowing of growth and deposition of pearl nacre on the nucleus, (ii) modification of food sources available to pearl oysters. The planktonic ecosystem 
of the atoll is presently dominated by picoplankton, made up of non-calcifying cyanobacteria and picoeukaryotes. The effect of acidification on phytoplankton is not known. But changing the structure of the plankton ecosystem may alter nutrient resources available to pearl oysters. Indeed, such a change might call into question the role of the trophic link between picoplankton and oysters. In the POLYPERL project, the analysis of trophic interactions between reared assemblages (oysters and epibiota) and the planktonic ecosystem wasperformed in situ. We have also addressed the role of epibiont communities on the diet of the pearl oyster (Lacoste et al, $2014 \mathrm{a}, \mathrm{b}$ ) to compare their potential influence on nutrient budget in these atoll lagoons (Lacoste and Mazouni, this issue).

Pearl culture in French Polynesia depends on the exploitation of a single species, the pearl oyster $P$. margaritifera. In addition to the lagoon ecosystem to maintain the capacity to provide services, sustainability can be approached from a genetic point of view, as different populations of this species can be isolated by hundreds of kilometres. The results obtained show a homogenisation of the genetic resources pearl oyster stocks of several atolls following massive inter-island transfers (Lemer and Planes, 2012). Indeed, these transfers, which increased greatly in response to the growth of the pearl industry, were done to artificially boost the size of the farmed populations. Besides health and environmental risks associated with these practices, the transfers have led to a genetic homogenization of populations on the pearl farming atolls. Now this risk has been recognised, it is urgent to preserve the genetic variability through the creation and maintenance of a reference population of wild genetic resources. The POLYPERL project has extended the analysis of diversity (Lemer and Planes, 2012) and identified the risk profiles, including those involving animal health (Tan et al., 2015).

\section{5- Socio-economic sustainability}

Pearl culture has a key position in Polynesia. This activity contributes not only to slowing down the human migration from the other islands to Tahiti, but also helps planning and economic development of these areas. This industry is currently undergoing an unprecedented crisis, with profits showing a continuing decline. The development history of the black pearl industry in French Polynesia is rather classic in terms of aquaculture development. But this development is also threatened by additional exogenous factors. Export-oriented aquaculture and high value aquaculture products are generally characterized by quickly increasing production, price declines and cyclical profitability. Such aquaculture products include cultured pearls but also, for instance, salmon, shrimp or seabass, which present similar trends 
(Tisdell 2003). The initial development is characterized by a rent period linked to the introduction and initial growth of the activity, where the sector develops dramatically, sustained by high prices at the farm gate, a relative small number farms and a low production at the industry level (Figure 3). A maturity step follows and the product then either goes into stabilization or decline. Regarding pearl oyster culture in French Polynesia, the trend is rather to decline with stabilization but very low average prices that do not cover production costs, underlining an overproduction according to the market context.

Faced with decreasing prices and the need for cash flow, pearl farmers have become trapped in a vicious circle by overstocking to balance lower production margins and harvesting and selling products before the economic optimum, which further pushes the price down. In addition to these difficulties, pearl culture is also facing external threats: (i) a structural constraint of the Territory's economy attached to the "atomic" rent, leading to high production costs (Poirine 1992); (ii) some environmental threats related to global change and its impact on oyster stocks; (iii) recent events in Japan (March 2011 earthquake), which will impact the black pearl market. The last of these difficulties underlines the dependency of the industry on its market and the fragility of development based on a single product for which there is fluctuating demand due to the luxury characteristics initially attached to it. A consequence of the difficulties faced could be perceived as a healthy shakeout for the industry, but behind the private profitability of farms, there is also a social dimension of pearl culture in French Polynesia, through local development and population fixation on remote archipelagos. Over its development, the Tahitian black pearl industry gradually changed from a luxury and high value-added product to a mass production product. But policies implemented are still the ones related to the luxury characteristics acquired during the rent period. This call for a change in the way stakeholders view the industry and a better division and differentiation of the range of products.

\section{6- Conclusion}

The great changes that have taken place in the pearl industry over the last ten years, both in production practices and due to the local and international economic situation, mean that a major (new and innovative) reorganisation of the industry needs to be thought-out. In terms of organisation, the pearl sector has progressed a great deal in these ten years, but to be ready and anticipate future change, this industry has also adopted and issued new regulations. Global change must be taken into account in the management and governance of the Tahitian pearl culture industry, considering the multiple perspectives of animal health, biology, 
environment and economics. The originality of the POLYPERL project was that it has offered the opportunity to simultaneously characterize different dimensions of the industry on the basis of a research approach (participative action research) that included the participation of the different stakeholders, producers, private businesses, and government services. These collective actions made it easier to bring together scientific and practical knowledge and thus the subjects examined.

The project designed provided close links between pure-science approaches, including the ecophysiology and genetic diversity of the species (Le Moullac et al. 2016a,b ; Blay et al. 2016), the interaction of pearl culture with the environment (Lacoste and Mazouni, 2016 ; Le Moullac et al. (2016a) and Blay et al. 2016), the strategies of businesses with regard to the proposed innovations (Latchere et al. 2016 ; Bertucci et al. 2016) and risk management, and, finally, the collaborative construction of indicators for monitoring the industry (Rey-Valette et al. 2015). In this context, the resultst of the research will contribute to the development of new technologies, strategies, tools and incentives for managing transitions and adaptations of Polynesian pearl culture in the context of global change.Another innovative aspect of the project was to bring together a very wide variety of disciplines which has combined their broad range of skills to answer questions on sustainable and integrated management of pearl culture in French Polynesia. Hence, in the frame of that project, we have obtained a precise evaluation of the current status of $P$. margaritifera genetic diversity in French Polynesia, an understanding of the relationship between pearl oyster recruitment and environmental conditions and a "model tool" to predict larval recruitment in the Ahe atoll (Andrefouet et al., 2016 ; Thomas et al., 2016). In addition, improved husbandry and grafting practices (Latchere et al., 2016) and designing breeding objectives for the genetic improvement of $P$. margaritifera (Le Pabic et al., 2016) have been described.

In the frame of the POLYPERL project, the analysis of potential for the improvement of eco-efficiency of pearl farming as part of a sustainable and integrated management approach has been done by exploring technical and organisational innovations at the farm level, but also at the level of professional organisations and governance. These approaches have helped us to foresee the evolution of jobs, training and regulatory methods to be implemented to facilitate innovation. To close the POLYPERL project, a symposium was organized to present all results of the project to professional of pearl farming. With a hundred participants, the profession mobilized to this day and has shown interest in the scientific results. 


\section{7- Acknowledgments}

This work was financially supported by the ANR funding, POLYPERL project (reference ANR-11-AGRO-006-01-POLYPERL).We declare we have no competing interests.

\section{References}

Andréfouët, S., Charpy, L., Lo-Yat, A., Lo, C., 2012. Recent research for pearl oyster aquaculture management in French Polynesia.MarinePollution Bulletin, 65, 407-14.

Andrefouet, S., Thomas, Y., Dumas, F., Lo C., 2016, Revisiting wild stocks of black lip oyster Pinctada margaritifera in the Tuamotu Archipelago: The case of Ahe and Takaroa atolls and implications for the cultured pearl industry, Estuarine, Coastal and Shelf Science, http://dx.doi.org/10.1016/j.ecss.2016.06.013

Bertucci F., Legraverant Y., Berthe C., Brooker R., Lo C., Lecchini D., 2016, Natural cleaning of the black-lip pearl oyster Pinctada margaritifera by butterflyfishes (Chaetodon) in French Polynesia, Estuarine, Coastal and Shelf Science, http://dx.doi.org/10.1016/j.ecss.2016.04.001

Blay, C., Parrad S., Cabral P., Aiho V., Ky C.L. 2016, Correlations between cultured pearl size parameters and PIF-177 biomarker expression in Pinctada margaritifera families reared in two contrasting environments, Estuarine, Coastal and Shelf Science, http://dx.doi.org/ 10.1016/j.ecss.2016.05.020

Charpy, L., Blanchot, J., 1998. Photosynthetic picoplankton in French Polynesia atoll lagoons: estimation of taxa contribution to biomass and production by flow cytometry. Marine Ecology Progress Series, 63, 253-259.

Chavez-Villalba, J., Soyez, C., Huvet, A., Gueguen, Y., Lo, C., Le Moullac, G., 2011. Determination of gender in the pearl oyster Pinctada margaritifera .Journal of Shellfish Research, 30, 231-240.

Cochennec-Laureau Nathalie, Montagnani Caroline, Saulnier Denis, FougerouseAngelique, Levy Peva, Lo Cedrik (2010). A histological examination of grafting success in pearl oyster Pinctada margaritifera in French Polynesia. Aquatic Living Resources, 23(1), 131140.

Delesalle, B., Sakka, A., Legendre, L., Pagès, J., Charpy, L., Loret, P., 2001. The phytoplankton of Takapoto atoll (Tuamotu Archipelago, French Polynesia): time and space 
variability of biomass, primary production and composition over 24 years. Aquatic Living Resources, 14, 175-182.

Doroudi, M.S., Southgate, P.C., 2003. Embryonic and larval development of Pinctada margaritifera (Linnaeus, 1758). Molluscan Research, 23, 101-107.

Dumas, F., Le Gendre, R., Thomas, Y., Andréfouët, S., 2012. Tidal flushing and wind driven circulation of Ahe atoll lagoon (Tuamotu Archipelago, French Polynesia) from in situ observations and numerical modelling.Marine Pollution Bulletin, 65, 425-40.

Fournier, J., Levesque, E., Pouvreau, S., Le Pennec, M., Le Moullac, G., 2012a. Influence of plankton concentration on gametogenesis and spawning of the black lip pearl oyster Pinctada margaritifera in Ahe atoll lagoon (Tuamotu archipelago, French polynesia). Marine Pollution Bulletin, 65(10-12), 463-470.

Fournier, J., Dupuy, C., Bouvy, M., Couraudon-Reale, M., Charpy, L., Pouvreau, S., Le Moullac, G., Le Pennec,M., Cochard, J.C., 2012b. Pearl Oysters Pinctada margaritifera grazing on natural plankton in Ahe atoll lagoon (Tuamotu archipelago, French Polynesia). Marine Pollution Bulletin, 65(10-12), 490-499.

Gueguen, Y., Mazouni, N., 2014. A pearl of a partnership.International innovation: disseminating science, research and technology, 125, 21-23. Open Access version: http://archimer.ifremer.fr/doc/00188/29925/.

Joly, J.P., Cochennec-Laureau, N., Fougerousse, A., François,C. 2007. Les réseaux d'épidémio-surveillance REPANUI et REPAMO. INRA Productions Animales 20, 229232.

Joubert, C., Piquemal, D., Marie, B., Manchon, L., Pierrat, F., Zanella-Cleon, I., CochennecLaureau, N., Gueguen, Y., Montagnani, C., 2010.Transcriptome and proteome analysis of Pinctadamargaritifera calcifying mantle and shell: focus on biomineralization. BMC Genomics 11, 613-625.

Joubert, C., Linard, C., Le Moullac, G., Soyez, C., Saulnier, D., Teaniniuraitemoana, V., Ky, C.L., Gueguen, Y., 2014. Temperature and Food Influence Shell Growth and Mantle Gene Expression of Shell Matrix Proteins in the Pearl Oyster Pinctada margaritifera. Plos One, 9 (8), e103944.

Ky, C.L., Blay, C., Sham-Koua, M., Lo C., Cabral, P. 2014. Indirect improvement of pearl grade and shape in farmed Pinctada margaritifera by donor "oyster" selection for green pearls. Aquaculture 432, 154-162. 
Le Pabic, L., Parrad, S. Sham Koua, M., Nakasai, S. Saulnier, D., Devaux, D., Ky, C.L. 2016. Culture site dependence on pearl size realization in Pinctada margaritifera in relation to recipient oyster growth and mantle graft biomineralization gene expression using the same donor phenotype, Estuarine, Coastal and Shelf Science (2016), http://dx.doi.org/10.1016/j.ecss.2016.03.009

Lacoste,E., Le Moullac, G., Levy, P., Gueguen, Y., Gaertner-Mazouni, N., 2014a. Biofouling development and its effect on growth and reproduction of the pearl oyster Pinctada margaritifera, in suspended cultures of French Polynesia.Aquaculture. 434, 18-26.

Lacoste, E., Gueguen, Y., Le Moullac, G., ShamKoua, M., Gaertner-Mazouni, N., 2014b. Influence of farmed pearl oysters and associated biofouling communities on nutrient regeneration in lagoons of French Polynesia. Aquaculture Environment Interactions. 5, 209-219.

Lacoste,_E., Gaertner-Mazouni, N., 2016. Nutrient regeneration in the water column and at the sedimentewater interface in pearl oyster culture (Pinctada margaritifera) in a deep atoll lagoon (Ahe, French Polynesia), Estuarine, Coastal and Shelf Science, http://dx.doi.org/10.1016/j.ecss.2016.01.037

Latchere O., Fievet J., Lo C., Schneider D., Dieu S., Cabral P., Belliard C., Ky C.L., Gueguen Y., Saulnier D., 2016, Effect of electrolysis treatment on the biomineralization capacities of pearl oyster Pinctada margaritifera juveniles, Estuarine, Coastal and Shelf Science (2016), doi: 10.1016/j.ecss.2016.06.014.

Le Moullac, G., Soyez C., Vidal-Dupiol J. Belliard C.,Fievet J., Sham Koua M., Lo-Yat A., Saulnier D., Gaertner-Mazouni N., Gueguen Y., 2016a. Impact of pCO2 on the energy, reproduction and growth of the shell of the pearl oyster Pinctada margaritifera, Estuarine, Coastal and Shelf Science, http://dx.doi.org/10.1016/j.ecss.2016.03.011.

Le Moullac, G., Soyez C., Latchere O., Vidal-Dupiol J., Fremery J., Saulnier D., Lo Yat A., Belliard C., Mazouni-Gaertner N., Gueguen Y., 2016b. Pinctada margaritifera responses to temperature and $\mathrm{pH}$ : Acclimation capabilities and physiological limits, Estuarine, Coastal and Shelf Science, http://dx.doi.org/10.1016/j.ecss.2016.04.011

Le Pennec, M., Anastas, M., Bichet, H., Buestel, D., Cochard J, Cochennec-Laureau, N., et al. 2010. Huître perlière et perle de Tahiti. Faaa, French Polynesia: HQ Imaging, p. 204.

Lemer, S., Planes, S., 2012. Translocation of wild populations: conservation implications for the genetic diversity of the black-lipped pearl oyster Pinctada margaritifera. MolecularEcology21, 2949-62. 
Linard, C., Gueguen, Y., Moriceau, J., Soyez, C., Hui, B., Raoux, A., Cuif, J.P., Cochard, J.C., Le Pennec, M., Le Moullac, G., 2011. Calcein staining of calcified structures in pearl oyster Pinctada margaritifera and the effect of food resource level on shell growth. Aquaculture, 313(1-4), 149-155.

Marie, B., Joubert, C., Tayale, A., Zanella-Cleon, I., Belliard, C., Piquemal, D., CochennecLaureau, N., Marin, F., Gueguen, Y., Montagnani, C., 2012. Different secretory repertoires control the biomineralization processes of prism and nacre deposition of the pearl oyster shell. Proceedings of the National Academy of Sciences of the United States of America 109, 20986-20991.

Millennium Ecosystem Assessment (MEA), 2005. Current state and trends assessment, Washington D.C., Island Press (http://www.unep.org/maweb/documents/document.354.aspx.pdf).

Pagès, J., Andréfouet, S., 2001.A reconnaissance approach for hydrology of atoll lagoons.CoralReefs, 20, 409-414

Poirine, B., 1992. Tahiti: Stratégie pour l'après-nucléaire. De la rente atomique au développement, Poirine B. (Editor), ISSN 2-907776-03-7, 307p.

Rey-Valette, H., _Lacoste E., Perez-Agúndez J., Raux P., Gaertner, J.C., Gaertner-Mazouni, N. (2015) Is sustainable development a motor or a constraint for the professionalization of the pearl oyster industry in Tahiti?, Estuarine, Coastal and Shelf Science, http://dx.doi.org/10.1016/j.ecss.2015.10.027

Southgate, P. C., Lucas., J.S., 2008. The Pearl Oyster, ELSEVIER.

Talvard, C., 2015. Points forts de la polynésie française. Bilan : la perle en 2014. Institut de la statistique de la polynésie française $6 \mathrm{p}$.

Tan, T.L., Paul-Pont, I., Evans, O.M., Watterson, D., Young, P., Whittington, R., Fougerouse, A., Bichet, H., Barnes, A.C., Dang, C., 2015. Resistance of Black-lip learl oyster, Pinctada margaritifera, to infection by Ostreid herpes virus $1 \mu$ var under experimental challenge may be mediated by humoral antiviral activity. Fish and Shellfish Immunology 44, 32-40.

Tayale, A., Gueguen, Y., Treguier, C., Le Grand, J., Cochennec-Laureau N., Montagnani C., Ky, C.L. 2012. Evidence of donor effect on cultured pearl quality from a duplicated grafting experiment on Pinctada margaritifera using wild donors. Aquatic Living Resources 25, 269-280. 
Tisdell, C., 2003. Economics and Marketing in Aquaculture: Farming Aquatic Animals and Plants, J.S. Lucas and Southgate P.C. (Editors), eds Blackwell Publishing Company, Chapter 12, pp 237-251.

Tisdell, C., Poirine, B., 2008. The Economics of Pearl Farming, in The Pearl Oyster, Southgate P. and Lucas J. Editors, 544p, pp473-497.

Thomas, Y., Garen, P., Courties, C., Charpy, L., 2010. Spatial and temporal variability of the pico- and nanophytoplankton and bacterioplankton in a deep Polynesian atoll lagoon. Aquatic Microbiology and Ecology, 59, 89-101.

Thomas, Y., Le Gendre, R., Garen, P., Dumas, F., Andréfouët, S., 2012.Bivalve larvae transport and connectivity within the Ahe atoll lagoon (Tuamotu Archipelago), with application to pearl oyster aquaculture management. Marine Pollution Bulletin, 65, 441452.

Thomas, Y., Dumas, F., Andréfouët, S., 2014.Larval dispersal modeling of pearl oyster Pinctada margaritifera following realistic environmental and biological forcing in Ahe atoll lagoon.PLoS One. 16;9(4):e95050. doi: 10.1371/journal.pone.0095050.

Thomas, Y., Thomas Y., Dumas F., Andrefouet S., (2016) Larval connectivity of pearl oyster through biophysical modelling; evidence of food limitation and broodstock effect, Estuarine, Coastal and Shelf Science, http://dx.doi.org/10.1016/j.ecss.2016.03.010 


\section{Figure 1}

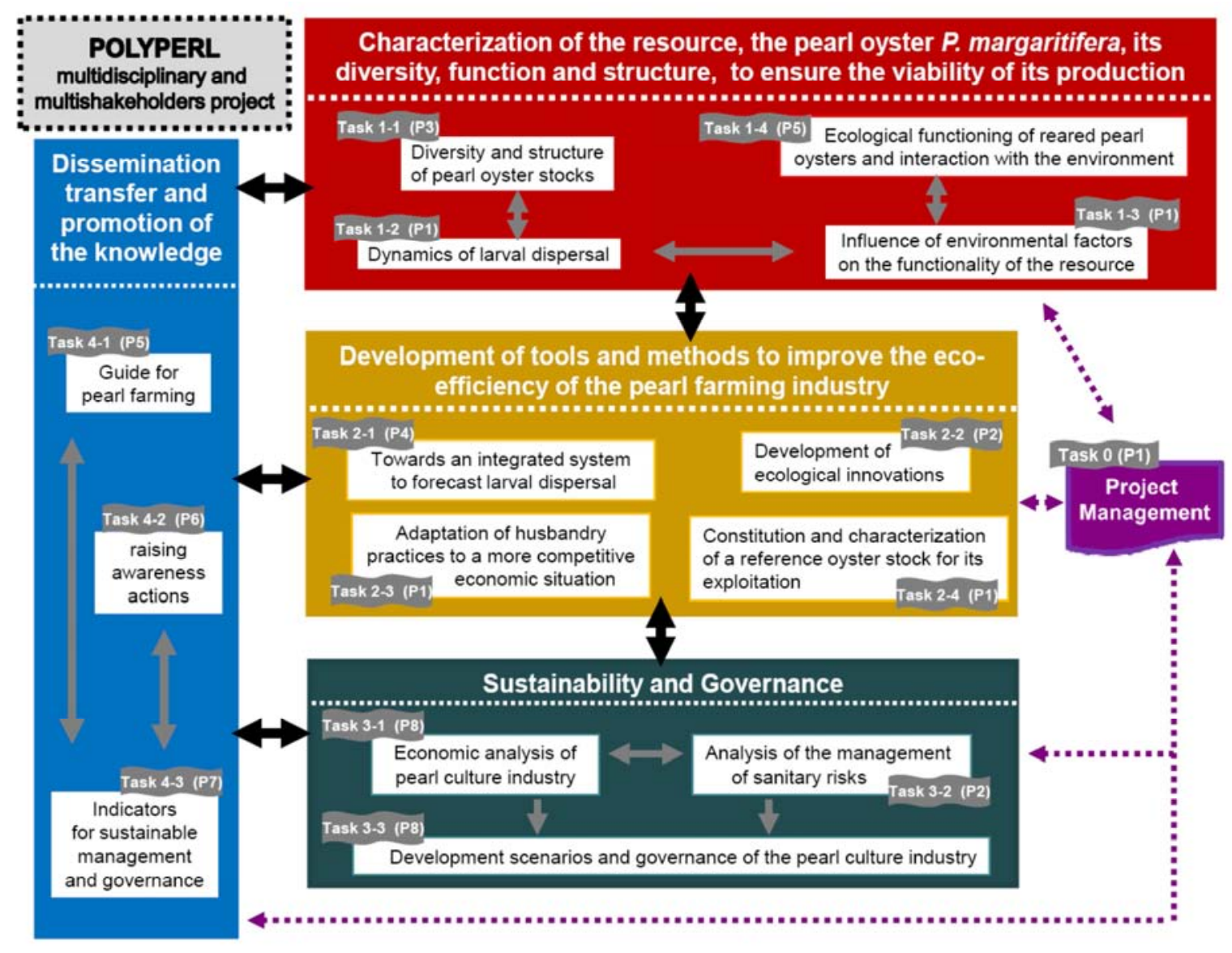

Figure1: Technical diagram of the ANR-POLYPERL Project (www.polyperl.org). POLYPERL is a global project taking into account an ensemble of research topics applied to "pearl farming" in French Polynesia and integrating risk management (anthropic, sanitary, social, economic and climatic). The objectives are to enable knowledge of the species and its culture and to provide innovations and decision-making tools in view of sustainable and integrated management of pearl culture in French Polynesia. The POLYPERL project is organised in 14 Tasks that are grouped in 4 Themes: (1) Characterization of the resource, the pearl oyster Pinctadamargaritifera, its genetic diversity, function and structure, so as to ensure the viability of its production; (2): Development of tools and methods to improve the eco-efficiency of the pearl farming industry, (3) Durability and governance and (4): Dissemination, transfer and promotion of the knowledge. 


\section{Figure2}

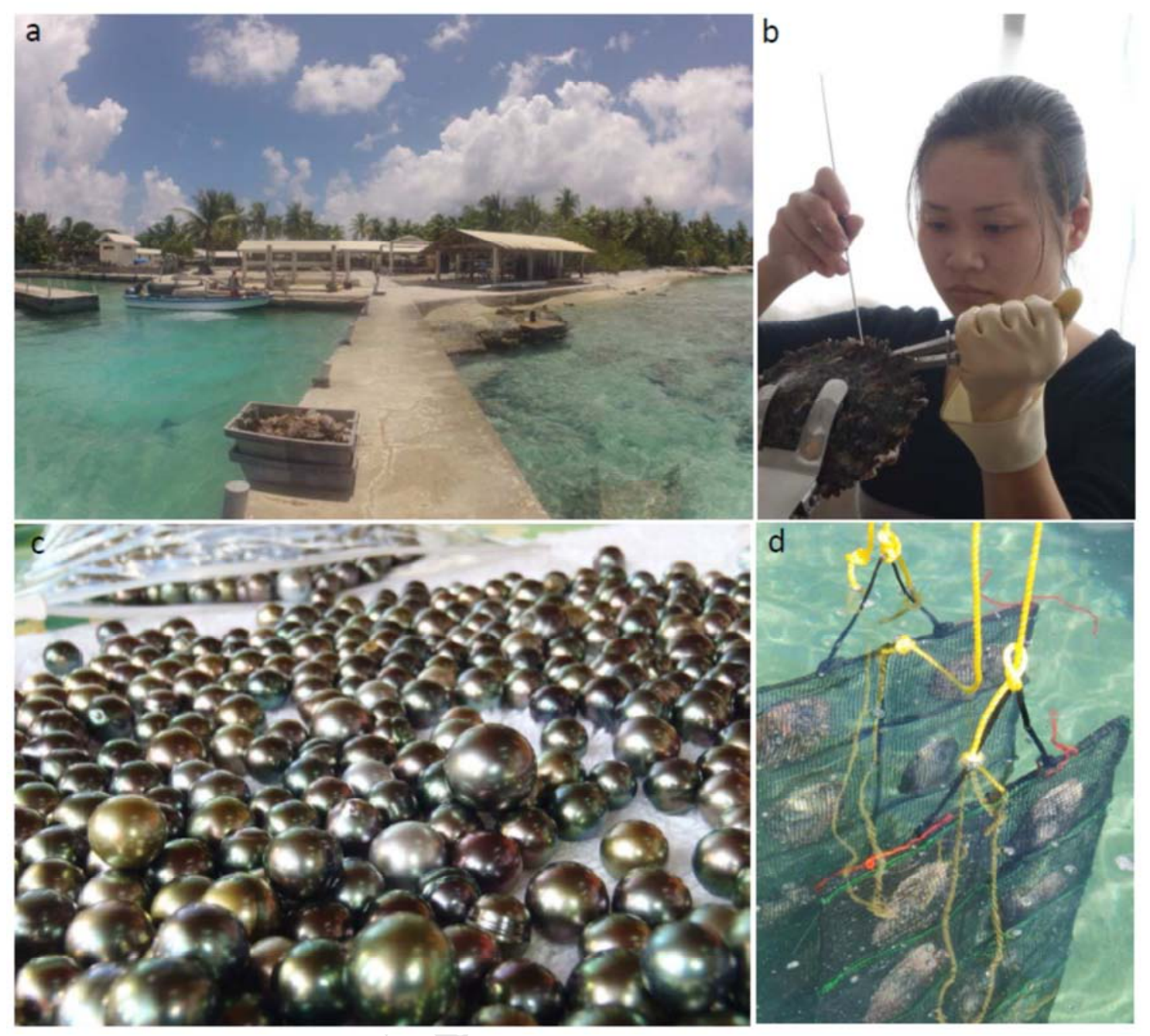

Figure 2: Pearl culture in French Polynesia. (a) Pearl farm in Rangiroa atoll; (b) Pearl oyster grating: during the grafting process, a small piece of mantle tissue from the donor oyster is inserted into the pearl pocket of the receiving oyster together with a nacre bead, the nucleus; (c) Harvest of colored pearls produced by the pearl oyster Pinctadamargaritifera. (d) Pearl oysters culture after grating. During the first 40 days after the graft, pearl oysters are cultured in retention baskets to assess the rejection of nucleus. (photos Y. Gueguen). 


\section{Figure 3}

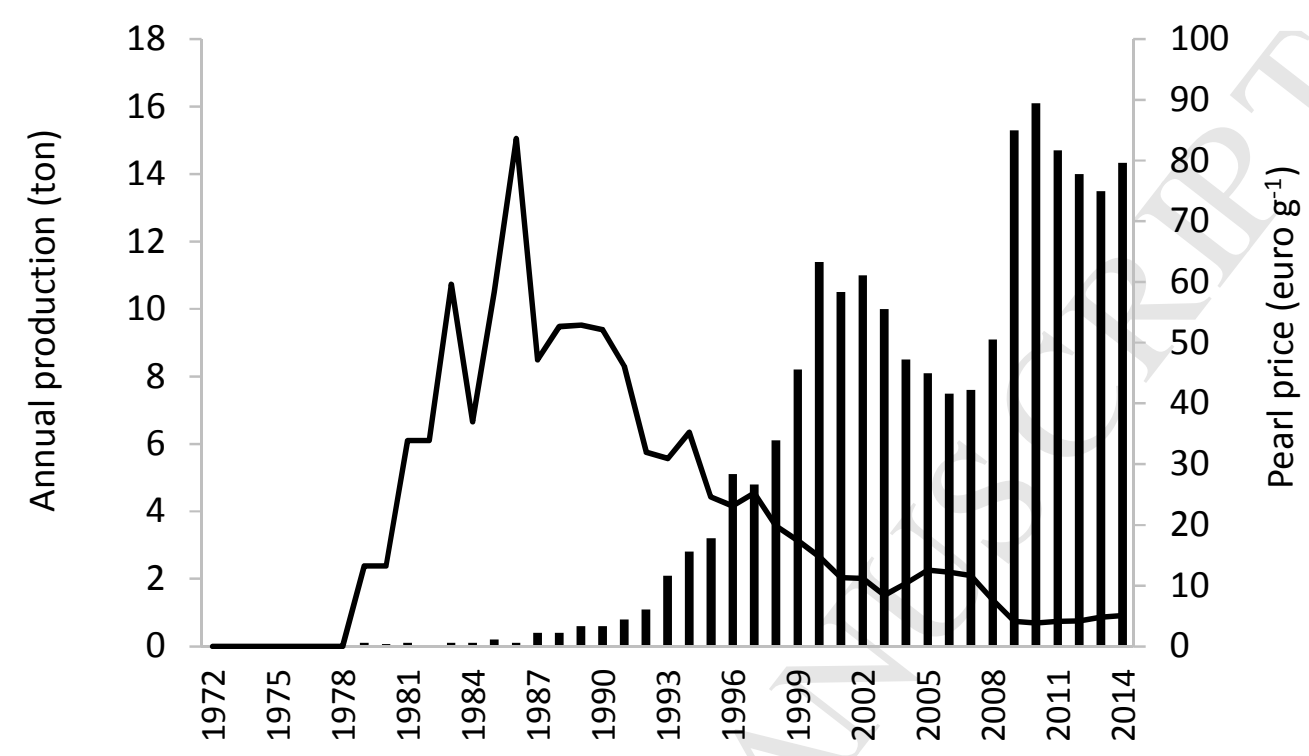

Figure 3 : Evolution from 1972 to 2014 of pearl price (euro per gram, line, scale at right) and total pearl weight exported(in ton, (bars, scale at left)). 